\title{
The Dragon's Deal: Educational Development and Knowledge Sharing in China-Africa Cooperation
}

Ehizuelen Michael Mitchell Omoruyi ${ }^{1 *}$, Okonkwo Chigozie Emmanual ${ }^{2}$, Bek Dhuorjang Choi Deng ${ }^{2}$, Moussa Keita ${ }^{3}$ and Joseph Mimbale $^{3}$

${ }^{1}$ Center for Nigerian Studies at the Institute of African Studies, Zhejiang Normal University, China

${ }^{2}$ College of Teacher Education, Zhejiang Normal University, China

${ }^{3}$ International Relations, Institute of African Studies, Zhejiang Normal University, China

\begin{abstract}
For decades, China has been unceasingly making headway on the modality and quality of educational collaboration. This educational collaboration comes through student exchange, joint initiatives (research) and special training programs for African educational officials, as well as other long- and short-term training of Africans in China. On the other hand, in the discourse about China-Africa relations, technology transfer is one of the less investigated subjects; however, technology transfers have existed in China-Africa cooperation in the form of knowledge sharing. The paper explores the following: (i) 'what' are transferred through knowledge sharing; (ii) the potential for cooperation in knowledge sharing between China and African countries that are core to economic development in the areas of agriculture, medical and knowledge sharing from China's development experience. Chinese methods of teaching 'how to develop' based on its own experience may help fortify the independence of African nations and build win-win cooperation for long-term development.
\end{abstract}

Keywords: Africa aid; China; Capacity building; Education; Knowledge sharing

\section{Introduction}

The increase in the number of African students in China is remarkable. The Ministry of Education reports that the number of African students' in China rose from 2,000 in 2003 to 49,792 in 2015 [1] (Table 1). Such Sino-African educational exchanges started small. They can be traced back to 1956 when China first established diplomatic ties with Egypt, and the two countries exchanged 8 students and teachers. China has established formal diplomatic relations with the majority of Africa's 53 nations and radically extended its presence across Africa. This educational cooperation represents a specific example of SouthSouth collaboration [2]. Since China turned out to be an important provider of overseas assistance through South-South cooperation in Africa, China's aid for educational development in Africa has evolved over several decades and is recently quite diverse and institutionalized in its scope and architecture. A lot of debate has considered how dissimilar China's assistance is from the West with snowballing idea that proposes that the Chinese have brought something dissimilar. For that reason, China's development assistance may be a good force in

\begin{tabular}{|c|c|c|c|}
\hline Year & $\begin{array}{c}\text { African } \\
\text { Students }\end{array}$ & Total Percentage & $\begin{array}{c}\text { Total International } \\
\text { Students }\end{array}$ \\
\hline 2003 & 1,793 & $2 \%$ & 77,715 \\
\hline 2004 & 2,186 & $2 \%$ & $1,10,844$ \\
\hline 2005 & 2,757 & $2 \%$ & $1,41,087$ \\
\hline 2006 & 3,737 & $2 \%$ & 162.695 \\
\hline 2007 & 5,915 & $3 \%$ & $1,95,503$ \\
\hline 2008 & 8,799 & $4 \%$ & $2,23,499$ \\
\hline 2009 & 12,436 & $5 \%$ & $2,38,184$ \\
\hline 2010 & 16,404 & $6 \%$ & $2,65,090$ \\
\hline 2011 & 20,744 & $7 \%$ & $2,92,611$ \\
\hline 2012 & 27,052 & $8 \%$ & $3,28,330$ \\
\hline 2013 & 33,359 & $9 \%$ & $3,56,499$ \\
\hline 2014 & 41,677 & $11 \%$ & $3,77,054$ \\
\hline 2015 & 49,792 & $13 \%$ & $3,97,635$ \\
\hline
\end{tabular}

Source: Chinese Ministry of Education (MOE) (2016).

Table 1: International students at Chinese institutes of higher education. solving this problem and achieving the new continental and globally sustainable development goals: African Agenda 2063 and the 2030 agenda for Sustainable Development Goals (SDGs). Recognizing the transformation in the world economy and the priorities of developing nations, education was placed at the core of the 2030 Development Agenda. In Africa, the African Union's 'Agenda 2063, the Africa we want', clearly articulate the need for an education and skills revolution.

Based on current policy discourse, is China making headway in its approach of educational collaboration in Africa? With the snowballing attention paid to China's soft power concerning the Chinese assistance modalities, education has been well-known as a significant component and even an inseparable part of China's South-South collaboration. According to Yuan, the author asserts that China offers 'aid' while seeking collaboration and exchange [3]. This is why the Chinese leadership uses the phrase 'China-Africa cooperation' more often than China's aid to Africa'. Also, Brautigam asserted that it is hard to calculate and evaluate China's aid according to the Western logic and modality framework as it is a developmental procedure for both of the donor rather than a 'prescription' operated by professional agencies [4]. Yuan also asserts that in the educational field, China likes to employ 'educational exchange' rather than 'educational aid'. Educational discourse and practice from the Chinese are provided with the focus on building two-way relations rather than professionally proposing development modalities. It is more than setting up a 'China model' but rather a procedure for lasting collaboration in the long

*Corresponding author: Ehizuelen Michael Mitchell Omoruyi, Researcher Center for Nigerian Studies at the Institute of African Studies, Zhejiang Normal University, China, Tel: 08613515964014; E-mail: mmacroe@yahoo.com

Received September 28, 2018; Accepted November 20, 2018; Published November 27, 2018

Citation: Omoruyi EMM, Emmanual OC, Deng BDC, Keita M, Joseph M (2018) The Dragon's Deal: Educational Development and Knowledge Sharing in ChinaAfrica Cooperation. J Hotel Bus Manage 7: 189. doi: 10.4172/2169-0286.1000189

Copyright: @ 2018 Omoruyi EMM, et al. This is an open-access article distributed under the terms of the Creative Commons Attribution License, which permits unrestricted use, distribution, and reproduction in any medium, provided the original author and source are credited. 
run. China's educational assistance and its features in practice are based upon diplomatic policies and China's distinctive win-win logic of foreign aid is serving bilateral relations rather than orthodox aid relations (which Yuan said is based on a 'catching up' logic) [5]. Does this mean China's educational collaboration comes with too much political rhetoric but dearth professional transformation of knowledge to Africa inhabitant? This research did discover some learning and teaching contradictions and noted that the collaborating universities chosen by China were good but very few were from the top line in China. Therefore, if quality transformation and communication can be ensured in Chinese universities, then education will contribute to a lasting and cooperative relationship between Africa and China' [3]. Notably, with an investigation into the policy discourse from the Chinese leadership, from 2009, signs of quality development in China's cooperative ties in education were presented in the action plans of the Forum on China-Africa Cooperation (FOCAC).

On the basis of tremendous commonalities of interest, China and African countries have succeeded in constructing bilateral and multilateral cooperation. Besides strengthening their relations, such educational cooperation would help Africa nations break away from being further marginalized globally, build a resilient economy, promote education as well as inclusive and sustainable industrialization and the fostering of multidisciplinary innovation. This can be seen from the strengthened one-on-one inter-institutional collaboration as well as improving and expanding cooperation on vocational education and training especially at the tertiary level. The Chinese government always place strong emphasis when it comes to offering vocational and professional training as well as university scholarship - both of which are led and conducted by various Chinese institutions [6]. This paper surveys the discourse evidence historically to recognize the educational trends in China-Africa cooperation. Apart from being useful to bilateral cooperation, will it contribute, stimulates and promote the economic changes essential for sustainable development in Africa?

\section{Global Perceptions of Sino-Africa Engagement: Reflections in the Literature}

Many Western perceptions of Sino-African engagement are negative because they consider Chinese development assistance to be expansive, exploitative, and dismissive of human rights. However, China's growing engagement on the continent is misunderstood and more complex than the critics would have us believe. Not surprisingly, China's presence in Africa has drawn great attention [7]. Scholars ponder the strategic and global implications of China's going to Africa [8]. Some explore the Chinese incentives and motives behind its active ventures in Africa as part of China's new global strategy for power and influence that may actually provide an opportunity for Africans to develop their economy [9]. Others view China's ventures in Africa as potentially new challenges to China itself as well as to the West [10]. Dispelling some 'fuzzy facts' about China's oil ventures in Africa, one study argues that the Chinese presence in Africa is quite similar to that by other multinational corporations [11], the colonial or neo-colonial predators acting aggressively for influence and wealth. Some wonder if the Sino-Western (especially European) competition in Africa may already be in China's favour [12]. As such the rise of China as a development partner has been one of the most important phenomena in the international development field over the past decade. As a "non-traditional" donor that has, to date, eschewing the OECD's Development Assistance Committee (DAC), China is forging a new path in development assistance $[13,14]$. However the implications of this emergence are not yet fully understood [15]. The author asserts that while China's rise creates space for "South-South" or "Triangular" modes of development cooperation, concerns over the lack of transparency in Chinese aid programs, and the apparently uninterested stance towards the governance implications of development lead many to wonder if Chinese engagement, on balance, will contribute to or undermine the efforts of traditional development partners [14,16-18].

Regardless of these concerns, China's approach to engagement as a development partner has differed significantly from that of the DAC donors, with efforts often focusing on infrastructure building and providing concessional loans to countries without conditionality [19]. Unlike most conventional western aid donors, which attach conditionality associated with appraisals of projects. China leaves its assistance apportionment decisions in the hands of the recipient government. This alternative focus has been appreciated by countries who have felt unduly constrained by DAC conditionality [20]. Development assistance plays a critical role as an economic incentive and punishment mechanism between nations. Literature on the allocation of aid by western donors exists, which emphasizes that aid is frequently given for political reasons rather than economic needs [21]. With the ongoing struggle for world power, new actors in the donor countries business appear and might use development aid to push through their interests. Only recently have scholars started analyzing the allocation of aid from these so-called emerging donors with quantitative methods. According to the results in Dreher et al., 'new' donors attach less importance to recipient need than the Development Assistance Committee (DAC) donors when allocating Aid [22]. However, concerns that commercial self-interest distorts the allocation of aid seem to be overstated for new and old donors alike. Arguably, these findings might be driven by the omission of the major 'new' donor, 'China'. China has been described as the chief villain among the 'new' donors. Naím characterizes its development aid as 'rogue aid' as it is not guided by the need in the developing countries, but rather by China's national interests [23].

The determinants of Chinese foreign assistance are, according to Naím, access to resources and boosting international alliances. Moreover, 'rogue donors' are said to undermine the development efforts of Western donors to promote good governance in the developing world. In addition, Chinese aid is accused of targeting future access to export markets and profitable investments [24,25]. Medical aid, for example, is considered as a tool to improve the reputation of Chinese medicine and as "a clever and low-cost way to introduce Chinesemade medications to the African market" [26]. Chinese aid is tied, which is a further indication that China uses aid to improve business opportunities $[27,28]$. However, this verdict is based on selective case studies only. No empirical study exists confronting the various claims about Chinese 'rogue aid' with data. This is because comprehensive data on the allocation of China's development aid are difficult to obtain. The prospect of China's cooperation has raised the possibility of changing the rhetoric and paradigm from one of "development", "assistance". "donor", "recipients" and even "partners" to one of "cooperation" and "mutual benefit" $[29,30]$. Beyond this, observers have seen new donors such as China as a potential balance to the existing OECD Development Assistance Committee (DAC) donor order, resulting in leverage for partner countries in the developing world [31]. Despite the arguments and to the contrary above, Chinese aid could be beneficial to Africa in so far as it fills a gap in development left by western aid conditionality. In many countries facing corruption problems, the institutions and economy are constraints to development which non-conditional Chinese aid can help to solve. Recipient countries, disillusioned with 
traditional forms of aid, have also welcomed the respect for sovereignty afforded by Chinese aid.

It is noticeable that although in the last 50 years China has forged cooperative relations in the field of education with 50 African countries, compared with the extensive discussions on China's economic relations with Africa, Chinese educational aid has received very little attention [32]. However, the Forum on China and Africa Cooperation (FOCAC), held every three years since 2000, has been making increasingly stronger promises in the field of education, particularly in its action plans at the 3rd Forum (Beijing Summit) in 2006 and the 4th Forum in 2009 [33,34]. Education is clearly shown as an important component in China's current African Policy [35] as stated: 'the Chinese Government will give full play to the role of its "African Human Resources Development Foundation" in training African personnel' and the 'exchange of students between China and Africa will continue'. Meskela et al. suggested that Chinese universities played an important role in bilateral cooperation. King used African students in China as an indicator of China's soft power, and Haugen analyzed China's policy for the enrolment of African students and its effect and outcome [36-38]. Others argued that China's educational assistance formed an essential part of China-Africa cooperation and offered substantial support to Africa [32,39]. Studies also discussed the management of African students or graduates in China, either in universities or society $[40,41]$. Other subject involves teachers who are doing language teaching and probing better ways to teach the Chinese language to Africans [42]. African students themselves wrote about their experiences in China and emphasized African agency in their behavior in Chinese society [43].

There are criticisms regarding the teaching methods and suggestions for improvement and different views on the effect of China's educational policy towards African students. One view holds that African scholarship holders are generally satisfied with their experiences in China, which thus promotes a positive view of the potential for strengthening China-Africa friendship with African countries through educational programs [44]. Although there are shortcomings and room for improvement, China's policy is rather successful in promoting China-Africa relations, building African capacity and bettering China's image [45-47]. Haugen, on the other hand, asserts that China fails to reach its policy objectives because of African students' disappointment with the quality of the education they receive, "Disappointment with the educational experience obstructs the promotion of Chinese values, thus obliterating the soft power potential of Sino-African educational exchanges" [38].

\section{Examining the Two Core Trends in China-Africa Educational Collaboration}

\section{Strengthen higher level education collaboration}

The new millennium witnessed the start of a new phase of cooperation between African countries and China. This new phase of cooperation was marked by the first FOCAC in October 2000, the cooperation became more institutionalized. The first FOCAC action plan (2000) reaffirmed China's commitment to increasing the number of government scholarships and inbound Chinese teachers to Africa. Significantly, the plan also established the African Human Resource Development Fund, to provide a more coordinated mechanism for training African professionals. Also, it was during this summit that countries jointly signed the Beijing Declaration of 2000, and issued the Program for China-Africa Cooperation in Economic and Social Development. With this program, ministers agreed to expand cooperation in education and human resources development. Since the earliest program which came to be an 'Action Plan' from the 2006 FOCAC onwards, set clear ideas in two key areas of what the Chinese government would promise in the field of education: training and scholarship. In addition, the Chinese leadership shows interests in fortifying University collaboration aims to facilitate university partnerships, which will profit the production of knowledge that promotes mutual understanding between China and African nations and the cultivation of top-level talents who can work effectively across borders. Several new kinds of collaboration were established when China and Africa met for the fourth FOCAC summit in 2009.

The 2009 FOCAC Action Plan (2010-2012) fortify the focus on higher levels of education and especially university collaboration, where 20 in China were twinned with 20 higher education institutions in top ranking institutions situated in 17 African nations under the strategy known as ' $20+20$ ' Cooperation Plan. Believing that universities play a critical role in the development of human resources and knowledge production, this $20+20$ scheme highlights the unique dimension of the Chinese leadership effort to promote cooperation in higher education with African nations. The initiative provides an attractive opportunity for the internationalization of Chinese universities. The Similar attraction also exists for numerous African Higher Education Institutions, as they have diversified their academic links beyond their historical Western partners [48]. The final twenty universities selected for the $20+20$ initiative included numerous renowned universities that were in the top 100 African universities ranking, like the Stellenbosch, Lagos, Pretoria, Nairobi, Cairo, Dar es Salaam, and Makerere. On the Chinese side, they included prestigious Universities like Beijing Language and Culture University, East China Normal University, Shanghai Normal University, Jilin University, Hunan University, and Peking University.

The initiative employed a one-to-one 'twinned' approach to cooperate, for instance, East China Normal University twinned with University of Dar es Salaam, Beijing Language and Culture University twinned with Suez Canal University, and Peking University twinned with Cairo University [49]. According to King, the author asserted that the $20+20$ collaboration which forms its mechanism could be seen as an aid project, nevertheless, it was perceived as 'symmetric' and long-term' by some Chinese staff on the ground [48]. In terms of the understanding of 'long term', the author asserted numerous university collaboration initiated by China in the 1990s are still functioning and are being given backing by Chinese staff. Most of them have been in the Africa continent for twenty years. There is a strong understanding among the Chinese staff both in the $20+20$ partnership and Confucius Institute that are engaged in a long-term commitment to their partner universities in Africa. According to Yuan, she gave a good example to back up the fact of the long-term commitment by mentioning Tanzania Dar es Salaam Institute of Technology (DIT) partnership with Xi' an Jiao Tong University since 1991 [50]. The university has received different kinds of educational assistance from China, including computer lab construction, postgraduate scholarships, and the Chinese government sending Chinese teachers to the university.

There is evidence that some of the Chinese staffs perceive their $20+20$ cooperation as a form of capacity building for these African universities. In this sense, the $20+20$ initiative is viewed as an aid project' [48]. Given the documents accepted at each of the five FOCAC summits, one can, therefore, infer that there are currently six kinds of educational cooperation between African countries and their Chinese partners: (i) scholarships and exchange students; (ii) sending teachers 
to Africa; (iii) cooperation projects; (iv) Professional seminars; (v) Cooperation among universities; (vi) the Confucius Institute. The latest FOCAC Action Plan (2013-2015), announced in 2012 that the Chinese government will continue to promote the $20+20$ scheme. Also, UNESCO asserted the 'UNESCO-China-Africa Tripartite Initiative on University Partnership in 2011, including the $20+20$ Cooperation Plan as 'an integral part of the initiative' [49]. Above all, most Chinese staffs perceive the cooperation as potentially symmetrical, even though the Chinese government provides most of the financing. The Chinese government promised to provide USD \$2 million yearly under the framework of the UNESCO trust fund to support education development programs, especially higher education in Africa. Also, additional scholarship opportunities for African students to study in China have expanded dramatically since FOCAC shifted its focus to higher education. In August 2016, for instance, eight Chinese universities led by the Wenzhou University in collaboration with Ghana Embassy in Beijing and Study in China Admission Systems (SICAS) have agreed to reserve slots for 1,000 Ghanaian students yearly. The universities have also agreed to provide 200 out of the 1,000 Ghanaian students with full scholarships to undertake various undergraduate and post-graduate programs. Cities like Beijing, Shanghai, and Chongqing, and several higher education institutions have established regional and institutional scholarships for African students.

\section{Capacity building development cooperation}

Another focus of China's South-South educational cooperation is in vocational education and training, where China promised to improve the quality of its training programs to Africa. The mechanism of this approach is not new to China, the Ministry of Education usually authorizes tasks for local universities and permits these institutions to organize and arrange the specific practices with African participants. In terms of establishing educational partnerships, there are certain Chinese universities that have the opportunity to educate African students with Chinese government scholarship. Such universities are Tianjin University of Technology and Education, Jilin University, China Agriculture University, and Zhejiang Normal University are designated by the Chinese Ministries of Education to conduct seminars and workshop for African nations. Ever since the introduction of FOCAC, China-Africa educational cooperation has attained remarkable outcomes, especially in human resources. To strengthen its relations with African nations, China established numerous large programs of capacity building for African officials in various fields. The Chinese government contributes to capacity building in African nations by subsidizing the training of primary and senior civil servants from African nations for short-term courses in economics, urban planning, transportation, customs affairs and agriculture. These training took place in prominent Chinese universities such as the University of International Business and Economics, Beijing, Jiaotong University, China Agricultural University and Renmin University [51]. Currently, China aims to promote Africa's independent educational development by strengthening Africa's capacity to create its own cultural and human resources. Africa has long been reliant on overseas assistance, which somehow has often failed to resolve many indigenous issues. Unlike other overseas assistance, China has implemented a non-interference strategy of sharing experiences with African nations, allowing African governments to forge their own development paths. The cooperation between the Chinese government and African nations has offered applicable expertise to African nations through knowledge sharing.

In 2000, China set up an African Human Resources Development Foundation for training African personnel. Furthermore, the 2003
FOCAC document, stepped up China's support for human resources development in Africa, aiming to train 'up to 10,000 African personnel in different fields' between 2003 and 2006, and emphasized: 'We are completely aware of the significance of talent training and capacity building to sustainable development in Africa and of the great potential for cooperation between China and Africa in human resources. In 2006, the Chinese government further committed its role in funding these programs [35]. This paved way for China to adopt a new African policy in early 2006. Cooperation in human resources development and education remains one of the main premises of the policy. Since its inception, the policy has offered a base for China's commitment to assist the continent of Africa to tackle the dearth of African-trained professionals. China has sent over 2000 experts to more than 50 nations to conduct technical training, this initiative successfully assisted these nations to improve their technical management capacity in different fields including, agriculture, handicraft, radio and television, energy, and cultural-sports [52,53]. In China's context, human resources development cooperation refers to different kinds of research training programs and other personnel exchange programs for developing nations [54]. The Chinese government took the training of professional personnel in developing nations, especially Africa as their responsibility in national educational development strategy [55].

These trainings can be categorized into two kinds: (i) the short-term training course (which run from 2-3 weeks) for African governments officials from different departments; and (ii) short-term course (which run between six months and a year) for training professionals, technicians, focusing on practical skills like agro meteorology, medical techniques, and hybrid rice technology $[51,56]$. Since the mid-1990s, China has been supporting the capacity building for other developing nations, including African nations by enlarging the scale of technical training and hosting training programs for officials from African nations to China. In 2008, the Ministry of Education and the Ministry of Commerce jointly established a master's education programs for developing nations. The objectives of these programs are to cultivate high-level human resources to accommodate the diverse needs of these developing nations. Between 2008 and 2011, there were 252 trainees from 40 different African nations participating in these programs [57]. Between 2000 and 2012, it was estimated that no less than 45,000 African professionals took part in the short-term training in China; these programs were funded by the African Human Resources Development Foundation [37]. Also, from 2010 to 2012, China ran training sessions with an overall capacity of 27,318 trainees for officials and technical personnel from 53 African nations. The training sessions covered the field of foreign affairs, agriculture, forestry, animal husbandry, fishing, medicine, manufacturing, healthcare, inspection and quarantine, climate change, industry, public management, energy, and social security [54]. Also, Chinese medical teams, agricultural experts, and enterprises situated in Africa have trained local people in an effort to enhance local technological capabilities and upgrading China-Africa cooperation in science and technology [58].

In the $5^{\text {th }}$ Ministerial Conference of the Forum on China-Africa Cooperation, the Chinese government announced "African Talents Program" to train 30,000 African professionals in various sectors; also, the second summit of the Forum on China-Africa Cooperation in Johannesburg in December 2015, Chinese President Xi Jinping announced the "10 major plans" to boost China-African cooperation between 2015-2018. This includes establishing a number of regional vocational hubs and several so-called capacity-building colleges" to address the continent's dearth of skilled workers. This will train 
200,000 technicians and offer 40,000 African students with chances for professional training $[54,59,60]$. Based on these increased numbers, the Chinese government placed particular emphasis on the 'quality' of its training: the Chinese leadership will continue to offer training for people from diverse sectors in Africa as the need arises, and pay special attention to raising the quality of such training. The Chinese government interest in international education cooperation is also inscribed in the Outline of China's National Plan for Medium and Long-term Education Reform and Development (2010-2020). It emphasizes the promotion of international aid to education through human resources development. This assistance will focus on developing African nations own human resources capacities and in return help, the Chinese government discovers other significant sectors for investment. That is why recently China is paying more attention to the quality of training they provide. Furthermore, in order to improve the quality of the training, under the human resource development cooperation, China decided to offer 18, 000 government scholarships and take measures to improve the content and quality of training programs within its African talent program' [59].

In terms of scholarship, China has increased its scholarships provision for African students from 18,000 in 2012 to 30,000 in 2015 and it was increased to 50, 000 in 2018 FOCAC meeting in Beijing. Approximately 40 percent of these scholarships are in the applied sciences, engineering or technology fields, reflecting the demands from the African countries to build up skills in these areas. The remaining scholarships continue to be in humanities, social studies and Chinese language. Other sources assert that the number of African students on Chinese scholarship had risen from 922 in 1996 to 7821 in 2014 [52,61]. Also, stipend levels for students have also increased substantially. The Geneva-based Network for International Policies and Cooperation in Education and Training (NORRAG) reports that, as of 2015, stipends for multiple categories of students-undergraduate and Chinese language students, masters' degree students, Ph.D. candidates, and visiting scholars between 75 and 78.57 percent. In other words, all signs point to increased support for African students seeking higher education in China. Due to the Chinese visa rules, most international students cannot stay in China after their education is completed. This prevents brain-drain and means that China is educating a generation of African students who-unlike their counterparts in France, the United States or the United Kingdom- are more likely to return home and bring their new education and skills with them. Most of the Chinese education aid channel to African students are design and implemented by the Ministries of Finance, Foreign Affairs, Commerce, and Education with coordination through the Foreign Aid Inter-Agency Coordination Mechanism.

\section{What are Transferred through Knowledge Sharing?}

It is interesting to note that in the previous action plans, 'Education' as a sub-heading was found under 'Cooperation in the field of development' (in 2009 Plan) or 'Cooperation in social development' (in 2006 Plan). In the 2012 Plan, the section 'Cooperation in the field of development' was divided into different areas of development cooperation such as 'Human resource development' (HRD) and 'Science and Technology Cooperation and Knowledge Sharing' (STCKS). Educational promises were also mentioned very often under HRD and STCKS; however, the subsection titled 'Education' was moved under 'Culture and People-to-people Exchange and Cooperation'. What does this move mean to us? It could be interpreted that, to the Chinese government, education firstly is serving cultural cooperation and people-to-people exchanges. This sets the official aim and the nature of China's cooperation in the field of education. The key is 'people'. Then what is being exchanged from people to people through educational practice? The 'Developmental cooperation' section describes what knowledge is transferred through the abovementioned university education, training, and research collaboration.

Education under this context not only brings knowledge contribution to the development of individuals, but also brings knowledge which can contribute to a win-win relationship (the development of both sides). To gain a lasting relationship between China and African countries and among people in the South, China's education and training as a tool of public diplomacy is bridging the Chinese government and the African public. However, this needs to meet the demands of the partner countries and their 'people'. Based on FOCAC pledges and official documents, the three priorities of China's knowledge transformation can be summarized as follows.

\section{Knowledge in certain areas}

Developing subjects key to economic growth. The 2012 Plan promised to make further contributions to African HRD in areas including 'agriculture, industry, health, education, communication, media, science and technology, disaster prevention and reduction and administration', through 'scholarships, workshops and training programs' [59]. These areas are China's key areas of foreign aid and cooperation in Africa, which are stated in the white paper on China's foreign aid, under the heading of 'promoting a new China-Africa strategic relationship'. The white paper declared that priority should be given to: agricultural development; infrastructure construction and integrated development; medical and healthcare cooperation; capacity building and coping with climate change. Therefore, we can see that the subject/discipline priority in education and training are closely linked to the main areas of China's foreign aid in Africa. This again illustrates how 'education' in the FOCAC context cannot be easily understood without knowledge of China's general aid policies and China's HRD support to Africa.

\section{Knowledge at a certain level}

Developing applied research and tertiary vocational education. As previously described, in the FOCAC plans it can be seen that China reduced its promises regarding primary education but strongly strengthened its efforts with higher education and research. In the vocational section, China also has a focus on vocational education at a tertiary level. It is to be noted that China used the term 'TVET' in its 2003 pledge but has not used this since the 2006 Plan which only promised to train 'professionals' in different areas. It can be seen that the reason for this is that China has an increasingly clearer idea on what it wishes to focus in 'vocational' section to Africa: it is vocational training rather than vocational education. The 2012 Plan promised 'vocational skills training' in the HRD section; this is described as: to 'provide assistance' for Africa's vocational skills training facilities, train professionals and technical personnel for African countries and, in particular, help African young people and women enhance their job skills' [59]. It does not specify the level of education here, but we can see discourse under the headings of HRD, STCKS and education all providing great interest in the field of higher education (e.g. 'government scholarships' and university-based short-term and long-term training).

From another perspective, the World Bank Vice President for the African Region, Diop talked about the importance of lessons from China in educational development at the tertiary level in Africa: 
'Africa needs a skilled labour force in order to experience growth like China's...there is room to learn from China, where more than 40 percent of all tertiary degrees are awarded in science, technology, engineering, and mathematics (the so-called "STEM" fields)...China's success in developing the skills needed to adopt technology has created the conditions to attract investment in manufacturing [62].'

Moreover, one distinctive character of China's support for tertiary vocational education is that China also has its own 'higher TVET' transformation underway. This is to transfer local higher institutions to applied technology university (or college) (ying yong ji shu da xue). According to a speech at the World Federation of College and Polytechnics (WFCP) 2012 World Congress from the SecretaryGeneral of the China Education Association for International Exchanges (CEAIE), in China in 2011, a total of $7.44 \mathrm{~m}$ students enrolled at 1,280 TVET institutions nationwide, which is almost half of the total number of higher education receivers. We call this higher TVET, which has the dual functions of both higher education and vocational/technological education, which bears the responsibility for cultivating advanced skilled people who are capable of competing in the international market' [63]. This has given China's cooperation the characteristic of two-way 'sharing' (and developing together) rather than simply a one-way 'transformation'.

\section{Direct knowledge of China's understandings and experience of development}

In fact, the forms and disciplines of educational cooperation may not be different from education in many other donors or partner countries. However, the knowledge transformation from China contains 'Chinese characteristics' which in many ways are fundamentally different from the West. The Chinese way of 'boosting productivity and the associated emphasis on rapid and large investments in human and physical capital, high savings rates, and an overarching ability to consistently drive toward long-term objectives', as Diop has argued, is attractive to both Africa itself and also international institutions such as the World Bank who has been systematically working on African development for decades [62]. Therefore, China's educational cooperation also has a focus on transferring its own developmental experience, which in terms of the logic is focused on 'what I did' rather than 'what you need to do (to catch up with me)'.

We can see how China prefers to share its own experience of some training topics from an interview conducted during my fieldwork in 2008 at the Tianjin University of Technology and Education (TUTE). They offer a training course in vocational education to African institutional administrators. The seminar topics of the training include the following: 'curriculum and teaching reforms of vocational education: based on a direction of employment', 'vocational education in developing countries: a comparative view', 'Educational development in China', 'vocational skill certification in China', 'administration models of vocational institutions in China', and 'developing vocational education in China'. In addition, there are some visiting activities to historical locations and to primary/secondary/vocational schools in China. Recently TUTE also held a 14-day short-term 'culture workshop' (wen hua yan xiu ban) for African Union young leaders. 11 young leaders from $\mathrm{AU}$ headquarters attended this workshop in June, 2015 [64]. The workshop covered not only Chinese traditional culture, but also 30 years' experience of opening-up, including Chinese traditional culture, Chinese vocational education development and reform, social development and youth employment, China-Africa economic cooperation and trade, etc. [65]. This case also indicates the broad concept of 'culture' in China's foreign policy, and China's preference for categorizing 'education' in the scope of culture.

The People's Daily (2015) published an article by Professor Humphrey Moshi from the University of Dar es Salaam who pointed out that, China's rapid economic development and sustainable development has provided the world with valuable experience of the factors for economic growth, including strengthened HRD, balanced growth in agricultural and manufacture, infrastructure development and so on. As he said, as China's development model has clearly shown, it is possible to catch up developed countries without the Washington Consensus [66]. As this was published very recently on 28th July this year, can we say that Moshi's words have provided some hints as to China's contribution and position in terms of the post-2015 agenda?

\section{China's Knowledge Sharing}

Knowledge sharing has always been one of the significant factors that were emphasized from the very beginnings of ChinaAfrica cooperation. When Premier Zhou Enlai visited Ghana in 1964, he proposed the Eight Principles for Technical Assistance and Economic Aid to other nations in a press conference in Ghana. The principles point out that the purpose of China's development assistance is assisting recipient nations to gradually attain self-reliance, independent development, offer best-quality equipment and material of its own manufacturing. It is also emphasized that in offering technical assistance, China should ensure that the personnel of the recipient nation completely master such systems. Evidently, this is a knowledge sharing process comprising of multilevel factors including the provision of technology, equipment and training personnel.

China's development experience provides a better reference point for Africa. While Africa is eagerly searching for a path to prosperity and strength, China can provide Africa with some exemplary models that can be learned and replicated. Yuan gave a very interesting illustration of the FOCAC action plan and how education was stretched to include knowledge sharing [5]. She mentioned that in the past action plans, 'Education' as a sub-heading was found under 'Cooperation in the field of development' (FOCAC 2009 Plan) or 'Cooperation in social development' (FOCAC 2006 Plan). In 2012 Plan, the section Cooperation in the field of development' was divided into diverse areas of developmental cooperation like 'Human resources development' (HRD) and 'Science and Technology Cooperation and Knowledge Sharing' (STCKS). Educational promises were also stated very frequently under the HRD and STCKS; nevertheless, the subsection titled 'Education' was shifted under 'Culture and Peopleto-people Exchange and Collaboration'. What does this shift mean for China-Africa relations? It could be interpreted that, to the Chinese leadership, education initially is serving as people-to-people exchanges and cultural collaboration. This set the official goal and the nature of China's collaboration in the field of education. The main emphasis is the 'people'. Then what is being exchanged from people-to-people through educational practice? The 'Developmental cooperation' section explains what knowledge is shared through the above-stated university training, research cooperation, and education. Based on FOCAC pledges and official documents, the five priorities of China's knowledge sharing can be summarized as agriculture, medical, telecommunication, infrastructure, and manufacturing, which are identified by African nations as top priority areas that would be very useful in achieving certain development targets, combating both extreme and moderate poverty. China has shared knowledge in diverse areas, two of the areas will be discussed below. 
Citation: Omoruyi EMM, Emmanual OC, Deng BDC, Keita M, Joseph M (2018) The Dragon's Deal: Educational Development and Knowledge Sharing in China-Africa Cooperation. J Hotel Bus Manage 7: 189. doi: 10.4172/2169-0286.1000189

Page 7 of 10

\section{Agriculture}

According to a recent study, agriculture is expected to create 43 percent of jobs over the next five years (Figure 1). Also, the sector due to its untapped potential for productivity gains and the creation of valueadded products will be the sector to produce the most entrepreneurs over the next five years [67]. Capturing this opportunity required updated knowledge in this field, this is why knowledge sharing should be a core in Sino-Africa collaboration. The Chinese government with its experience in poverty alleviation is aware of this scenario that is why the Chinese government has attached great significance to conducting bilateral exchanges and collaboration with Africa on agricultural technology. China has sent delegations on study trips to Guinea-Bissau, Sierra Leone, and Zambia for potential agricultural collaboration, investment, and development. The Chinese government has also made early-stage preparations and investigations for the construction of agricultural technology demonstration center in Africa. Also, the government has developed for Angola and Mozambique agricultural plans and comprehensive disease and pest prevention and control plans for the cashew production and implemented technical collaboration of mushroom cultivation in Egypt. The agricultural technical education training program implemented under the collaboration between China and Nigeria stands as a successful case for China-Africa agricultural knowledge sharing.

In 2003, 500 Chinese experts took part in the Nigerian National Special Program for Food Security, financed by the Food and Agricultural Organization of the United Nations [68]. The experts, based in the 36 Nigerian States, have helped the benefiting communities overcome the dearth of water supply for drinking and irrigation while training local farmers in planting, fishing and beekeeping skills. In another incident, Brautigam asserts China's effort in agricultural assistance program with the Gambia and Sierra Leone [69]. Although the projects took different forms, both involved the development of swamp and upland areas for irrigated rice cultivation, with the goal of introducing intensive Chinese technology to boost production of rice, the main staple in both countries. Although these transfers did not generate the expected outcomes, as the local, economic, political, and social contexts were not given sufficient consideration during the project design stage; but, both projects were intended to help individual small farmers. We find another example in Burkina Faso during the late 1980s, where three rice planting areas turned out to be recognized nationwide, one changing from a small village to a town of over 8000 populaces [70]

In the year 1987, the net income of each peasant family in the region climbed from 400,000 to 800,000 African Francs (US\$1300-2600) [70] Due to this achievement, farmers from neighbouring nations migrated to the rice planting areas. This attainment is closely connected with Chinese experts' hard work, who taught local Burkina Faso's the organizational capacity, experience, and management skills of farming. Based on the knowledge shared by these Chinese agricultural experts, the Burkina Faso government awarded them each a National Medal in 1988 [71]. Additionally, in 2001, the Ministry of Agriculture in China and the Ethiopian Ministry of Agriculture signed the letter of intent on conducting collaboration in Agricultural Education and Training and Green Certificate. This will help both sides build an agricultural value chain and increase independent grain production capacity to boost food security, enhance the competitiveness of agricultural products and other speciality industries in both nations, above all, strengthen their collaboration on agricultural knowledge sharing. From 2001 to 2012, the Chinese government and the Ethiopian government have jointly implemented ten training programs. China collaborated with Ethiopia to develop vocational and technical education and training in agriculture, and China has sent over 400 people to Ethiopia to share their knowledge with 1800 teachers as well as 35,000 agricultural technicians in six majors including home economics, husbandry, crop cultivation, agricultural machinery, veterinary, and development of natural resources, with 66,000 students under training in local agricultural vocational colleges [61].

\section{Medical field}

Knowledge sharing has been broadly discussed in healthcare environments. It has been universally agreed that suitable knowledge sharing processes, based on good practices of knowledge creation, storage, transfer, and utilization, are fundamental to resolving daily medical problems. In the work of the Chinese Medical Team (CMT) to Africa, Chinese doctors also passed their expertise to local medical staff and assisted nations from Africa to develop health services. For instance, in Tanzania, to make African trainees better understand acupuncture, CMT members permitted the local trainees to practice on their own bodies, thereby offering direct tuition on the technique. In this way, they trained a large number of medical specialists. Furthermore, the Chinese Medical Team made the best use of local

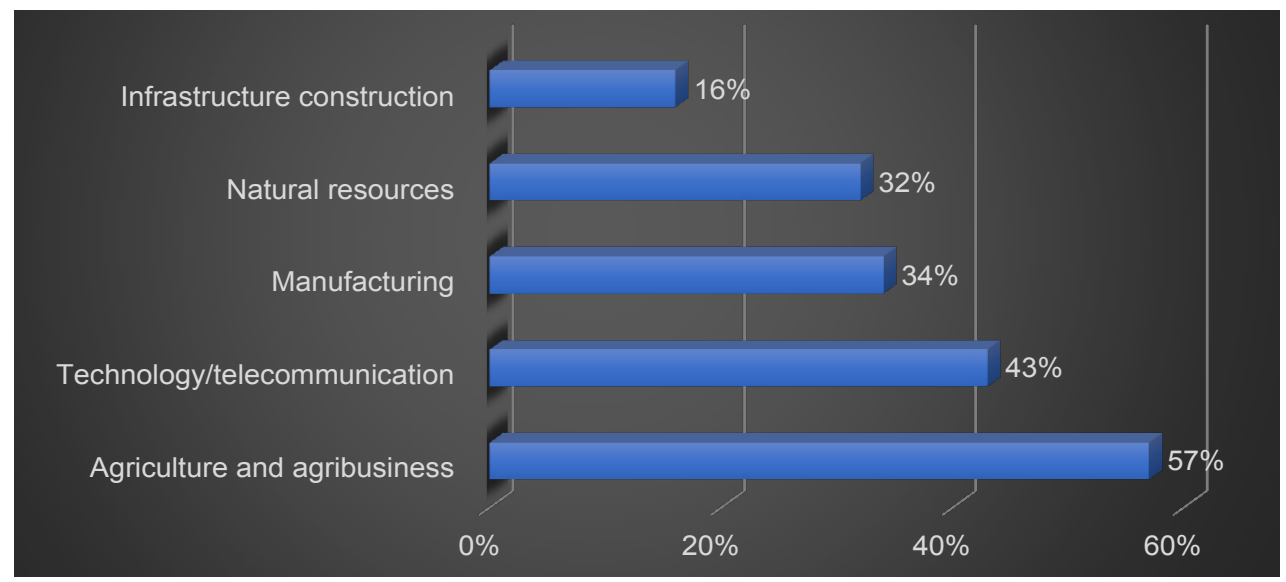

Source: Forbes Insight, 2016.

Figure 1: Industries/sectors that will create the most employments for young people over the next 5 years. 
media to publicize their medical knowledge [72-75]. Chinese doctors also assisted in establishing medical specialist and technical facilities.

Acupuncture is now extremely popular in several African countries such as Tunisia, Cameroon, Lesotho, Namibia and Madagascar [70]. China holds uninterrupted training programs either in Africa or China to offer knowledge of anti-malaria measures to African medical specialists and government officials. Chinese Medical Team (CMT) doctors from Ningxia Province offer medical workers the opportunity to learn new medical skills from them; they compiled a book entitled One Hundred Cases of Prevention and Treatment of African Children's Brain Malaria as a reference work for Benin doctors. Furthermore, in Algeria, up to 2008, the CMT put on over 20 training courses, gave more than 30 lectures and trained over 300 medical personnel who have turned out to be the backbone of local medical institutions [70,76,77]. West Africa's Ebola outbreak that affected Sierra Leone, Liberia and Guinea witnessed the importance of China's partnership in fighting the disease. During this Ebola outbreak, the medical skills of over 13,000 health workers and health professional were improved through training and capacity development [58]. With hard working and contribution, CMT doctors have won respect and praise from the governments and people of these nations.

\section{Knowledge sharing through China's development experience}

Clearly human capital has been one of the many enabling factors in China meteoric growth. Africa needs a skilled labour force in order to experience growth like China and alleviate poverty. China-Africa educational cooperation can be a better platform for China to sharing its knowledge of development with Africa. However, the knowledge sharing from China contains 'Chinese characteristics which in numerous ways are fundamentally dissimilar from Western nations. According to Diop, he asserted that The Chinese ways of bolstering productivity and the related emphasis on speedy and large investments in human and physical capital, high savings rates, and an overarching capability to consistently drive towards long-term goals' is attractive to both African nations and also international institutions like the World Bank who has been systematically working on African development for decades [62]. So, the Chinese educational cooperation also has a focus on sharing its own developmental experience. We can see how China prefers to share its own development experience through some recent training at the Tianjin University of Technology and Education (TUTE). The Chinese provide a training course in vocational education to African institutional administrators in the area of 'curriculum and teaching reforms of vocational education based on a direction of job opportunities, 'vocational education in developing nations, a comparative view', Educational development in China', 'vocational skill certification in China' 'administration models of vocational institutions in China', and 'developing vocational education in China'.

Recently, Tianjin University of Technology and Education (TUTE) held a 14-day short-term 'culture workshop' for African Union young leaders. In June, 2015 eleven young leaders from the African Union headquarters take part in this workshop [5]. The workshop covered not only Chinese culture, but over three decades of experience of reform as well. China's rapid economic transformation and its impressive development trajectory have clearly displayed, it is possible to catch up developed countries without the Washington Consensus [5]. This may provide a model for Africa, where China's presence has grown immensely over the same period. Looking at this, it is clear that one of the major priorities is to develop human resources through better education, support innovation within Africa so that it starts to have more of its own proprietorial technology in high growth, better investment return areas, and does much more on delivering green energy and sustainability.

FOCAC should seize this critical opportunity to align its aims in order to meet the new continental and globally sustainable development goals: African Agenda 2063 and the 2030 agenda for Sustainable Development Goals (SDGs) and incorporate concrete sustainable development goals into future plans in Africa. FOCAC has enhanced economic cooperation and development in China and Africa over the past 16 years: now it can pave the way towards a more sustainable and equitable future. In order to realize the world where no one is left behind, poverty reduction policies and know-how that was able to get over 700 million Chinese out of poverty as well as successful policies and know-how from developed nations should be shared and made available to developing nations, especially African countries trying to lift their population out of poverty. This is a key step to achieve the Sustainable Development Goals.

\section{Conclusion}

China's aid for educational development in Africa has evolved over several decades and is recently quite diverse and institutionalized in its scope and architecture. From official discourse, we can see that China is engaging in a higher 'quality' South-South cooperation where education and especially the higher level of education plays a significant role in boosting the sustainability of China-Africa relations. Universities as platforms are connecting vocational training, formal higher education, academic research and think tanks from the two sides together, transferring China's development lesson to Africa. Overall, these various cooperation programs seem to signal a determination to take the relationship between China and Africa beyond the purely commercial level.

Access to knowledge by rural communities in Africa will serve as a panacea to the problems that long time exist and hindered them from exploiting their potentialities. Rural community development is the backbone of a country's development, ignoring rural communities for not providing them with basics needs and access to information infrastructures will basically lead them to migrate from rural communities to concentrate in the urban areas which will not augur well for African development. Recently, there is a distinct and unprecedented shift towards strengthening science and technology capacity and learning how knowledge can be more directly applied to improve people's livelihoods in Africa. However, for the present situation of technology transfer, there is much room for improvement in order to achieve mutual benefits. African and Chinese leaders strongly put more emphasis on "knowledge sharing" in form of technology transfer; this is a promising sign. This obligation suggests that China's development assistance may be a good force in achieving the Sustainable Development Goals in Africa.

Furthermore, cooperative ties in education have been developed in time and cemented with the creation of the Forum on China-Africa Cooperation (FOCAC). On the basis of tremendous commonalities of interest, China and African countries have succeeded in constructing bilateral and multilateral cooperations. Besides strengthening their relations, such educational cooperation would help Africa nations break away from being further marginalized globally, build a resilient economy, promote education as well as inclusive and sustainable industrialization and the fostering of multidisciplinary innovation. Economic growth and social development are heavily dependent on investment in education, sustainable industrial development, and technological progress. 
Citation: Omoruyi EMM, Emmanual OC, Deng BDC, Keita M, Joseph M (2018) The Dragon's Deal: Educational Development and Knowledge Sharing in China-Africa Cooperation. J Hotel Bus Manage 7: 189. doi: 10.4172/2169-0286.1000189

Page 9 of 10

In terms of academic initiatives, China-Africa cooperation should be reinforced in teaching, research and management to support human resources need in Africa as local economies develop. Joint research laboratories should be established in African nations to develop fields necessary to face future challenges such as nanotechnology and material science, biotechnology for health and agriculture, informatics, alternative sources of energy and the social sciences. An effort should be made to upsurge opportunities for student exchange at all levels, to build mutual consensus and confidence. Also, a concerted effort should be made to train semi-skilled and managerial African personnel in areas where there are active Chinese economic investment and a dearth of African expertise. The spheres of China-Africa development partnership should be stretched to include non-state actors from both sides - so as to produce adequate capacity and synergies for executing China-Africa development involvement. The potential advantage of China-Africa cooperation can be severely threatened or even eroded if China reproduced similar patterns of dependency associated with the contemporary North-South relationship. All these suggestions can act as possible avenues of action to make the China-Africa relationship more durable and productive-a relationship that is profitable to both partners and to future generations.

\section{References}

1. China releases report on foreign students for 2015 (2016) Ministry of Education, China (MOE).

2. Chen Y, Zhang J (2015) Qiannian Fazhan Mubiao Jinru Jianshouzhinian Weilaigeng Guanzhu Xiaochu Pinkun he Gongtong Fazhan.

3. Tingting Y (2014) Diploma serves diplomacy: China's 'donor logic' in educational aid, China: An International Journal 12: 87-109.

4. Brautigam D (2011) Aid with Chinese Characteristics: Chinese Foreign Aid and Development Finance meet the OECD-DAC aid regime. J Int Dev 23: 752-764.

5. Tingting $Y$ (2015) Teaching to fish' rather than 'giving a fish': Is China contributing to the global sustainable futures? Academics in China 12: 257-266.

6. Reilly J (2015) The Role of China as an Education Aid Donor, Paper Commissioned for the EFA Global Monitoring Report 2015, Education for All 2000-2015: achievement and challenges.

7. The Chinese in Africa: Trying to pull together. The Economist (2011).

8. Stall AK (2011) Contrasting rhetoric and converging security interests of the European Union and China in Africa. J Current Chinese Affairs.

9. Kitissou M (2007) Africa in China's Global Strategy.

10. Raine S (2009) China's African Challenges London.

11. Down ES (2007) The fact and fiction of Sino-African energy relations. China Security 3: 42-68.

12. Bangui T (2011) China: A New Partner for Africa's Development-Are We Heading for the End of European Privileges on the Black Continent?

13. Kim S, Lightfoot S (2011) Does DAC-Ability 'Really Matter? The emergence of non-DAC Donors: Introduction to Policy Arena. Journal of International Development 23: 711-721.

14. De Haan A (2011) Will China change international development as we know it? Journal of international development 23: 881-908.

15. Kelly G, Brazys S, Elkink JA (2016) The Dragon's Curse? China, the World Bank, and Perceptions of Corruption in Tanzania. Aid Data, Working Paper 26.

16. Zimmermann F, Smith K (2011) More actors, more money, more ideas for international development co-operation. J Int Dev 23: 722-738.

17. Abdenur AE (2014) China and the BRICS Development Bank: Legitimacy and Multilateralism in South-South Cooperation. IDS Bulletin 45: 85-101.

18. Strange AM, Park B, Tierney MJ, Fuchs A, Dreher A, et al. (2013) China's development finance to Africa: A media-based approach to data collection. Center for Global Development working paper (323).
19. Wang FL, Elliot EA (2014) China in Africa: presence, perceptions and prospects. Journal of Contemporary China 23: 1012-1032.

20. Zhao S (2014) A neo-colonialist predator or development partner? China's engagement and rebalance in Africa. J Contemp China 23: 1033-1052.

21. Alesina A, Dollar D (2000) Who Gives Foreign Aid to Whom and Why? J Econ Growth 5: 33-63.

22. Dreher A, Nunnenkamp P, Thiele R (2011) Are 'New' Donors Different? Comparing the Allocation of Bilateral Aid between Non-DAC and DAC Donor Countries, World Development 39: 1950-1968.

23. Naím M (2007) Rogue Aid, Foreign Policy 159: 95-96.

24. Davies P (2007) China and the End of Poverty in Africa - Towards Mutual Benefit? Diakonia, Alfaprint, Sundyberg, Sweden.

25. Lum T, Fischer H, Gomex-Granger J, Leland A (2009) China's Foreign Aid Activities in Africa, Latin America, and Southeast Asia, Congressional Research Service Report.

26. Shin D (2006) Africa, China and Health Care, Inside Asia 3-4, Oct/Dec: 14-16.

27. Pehnelt G (2007) The Political Economy of China's Aid Policy in Africa, Jena Economic Research Paper.

28. Schuller M, Brod M, Neff D, Bunte M (2010) China's Emergence within Southeast Asia's Aid Architecture: New Kid on the Block?

29. Grimm S (2014) China-Africa Cooperation: promises, practice and prospects Journal of Contemporary China 23: 993-1011.

30. Six C (2009) The Rise of Postcolonial States as Donors: a challenge to the development paradigm? Third World Quarterly 30: 1103-1121.

31. Kragelund P (2011) Back to BASICs? The Rejuvenation of Non-traditional Donors' Development Cooperation with Africa. Development and Change 42 $585-607$.

32. Baoping L (2007) On the issues concerned with China-Africa educational cooperation

33. FOCAC (2006) Forum on China-Africa Cooperation: Beijing Action Plan (20072009).

34. FOCAC (2009) Forum on China-Africa Cooperation Sharm el Sheikh Action Plan.

35. China's African policy (2006) Ministry of Foreign Affairs, China (MOFA).

36. Meskela K, XU Jialing, Qiang LI (2009) The Research on Educational Cooperation Between China and Africa: An African Perspective. Studies in Foreign Education 36: 50-53.

37. King K (2013) China's Aid and Soft Power in Africa the Case of Education and Training. Suffolk: James Currey.

38. Haugen $H \varnothing$ (2013) China's recruitment of African university students: policy efficacy and unintended outcomes. Globalisation, Societies and Education 11:315-334.

39. Shizhou L, Hui X (2012) The development and transition of China-Africa educational cooperation in the new period. Educational Research10: 28-33.

40. Jianghua $Z$ (2013a) Construction of community management system for foreign students in universities. Vocational and Technical Education 34: 66-68.

41. Jianghua Z (2013b) Exploration of compound applied talents training mode on African Students. Journal of Tianjin University of Technology and Education 23.4: 64-70.

42. Lunlun L, Mengya R (2010) A sociolinguistic study upon Chinese language learning concept of African overseas students. J Han Shan Normal University

43. Lloyd GA (2012) Africa in China: Affirming African Agency in Africa-China Relations at the People to People Level.

44. Dong L, Chapman DW (2008) The Chinese Government Scholarship Program: An Effective Form of Foreign Assistance? International Review of Education 54: $155-173$

45. Anshan L, Haifang L (2013) The evolution of the Chinese policy of funding African students and an evaluation of the effectiveness. Draft report for UNDP.

46. Changsong N (2016) A survey of African students' satisfaction of Chinese Government Scholarship. 
Citation: Omoruyi EMM, Emmanual OC, Deng BDC, Keita M, Joseph M (2018) The Dragon's Deal: Educational Development and Knowledge Sharing in China-Africa Cooperation. J Hotel Bus Manage 7: 189. doi: 10.4172/2169-0286.1000189

Page 10 of 10

47. Liu Haifang (2017) A study on the evolution and effect of China's scholarship policy towards African students. In Li Anshan and Liu Haifang, Annual Review of African Studies in China 2015.

48. King K (2014) China's Higher Education Engagement with Africa: A different Partnership and Cooperation model?

49. United Nation Educational, Scientific and Cultural Organization (UNESCO) (2017) List of Selected Universities in 20+20 Cooperation Plan of Chinese and African Institutions of Higher Education.

50. Tingting Y (2011) Chinese Educational 'Aid' to Africa: A Different 'Donor Logic'?

51. Niu C (2014) China's educational cooperation with Africa: Towards new strategies partnerships. Asian education and development studies 3: 31-45.

52. Liu H, Li A (2014) Evolution of the Chinese policy of funding African students and an evaluation of its effectiveness, Draft of UNDP Project.

53. China's Information Office of the State Council (2014) White Paper on China's Foreign Aid.

54. Shoko Yamada (2016) Post-Education-for-All and Sustainable Development Paradigm: Structural Changes with Diversifying Actors and Norms, Emerald Group Publishing Limited.

55. The State Council (2010) Outline of China's National Plan for Medium and Long-term Education Reform and Development (2010-2020).

56. Nordtveit BH (2011) An Emerging Donor in Education and Development: A Case of China in Cameroon. Int J Edu Development 31: 99-108.

57. China releases report on foreign students for 2015, Ministry of Education, China (MOE) (2012) Retrospect and prospect on China-Africa Educational Exchanges and Cooperation in the New Century.

58. Tambo E, Ugwu CE, Guan Y, Wei D, Xiao-Ning, Xiao-Nong Z (2016) ChinaAfrica Health Development Initiatives: Benefits and Implications for Shaping Innovative and Evidence-Informed National Health Policies and Programs in Sub-Saharan African Countries. Int J MCH AIDS 5: 119-133.

59. FOCAC (2012) The Fifth Ministerial Conference of the Forum on China-Africa Cooperation Beijing Action Plan (2013-2015).

60. Ministry of Commerce (MOFCOM) (2015) The Interpretations of the Johannesburg Summit of the FOCAC and the Sixth Ministerial Conference on the 10 Major China-Africa Cooperation Plans in Economic and Trade Domains.

61. Wan X (2015) The trend of China's Aid to African Education. Norrag News, 52: $133-135$
62. Diop M (2015) Lessons for Africa from China's Growth.

63. Jiang B (2012) China's TVET: Reform and Opening Up-Speech at the WFCP 2012 World Congress.

64. TUTE (2015) The 2015 African Union Young Leaders Culture Workshop Opening Ceremony.

65. China's Foreign Aid (2014) Information Office of the State Council.

66. FOCAC (2015) The Forum on China-Africa Cooperation Johannesburg action plan (2016-2018).

67. Forbes Insights (2015) Job Creation in Sub-Saharan Africa: Entrepreneurs Governments, and Innovation. Partnership with Djembe Communications.

68. Liu K (2015) China-Nigeria bi-national relations, productively on high speedChinese Consul General, Vanguard.

69. Brautigam D (1992) Land Rights and Agricultural Development in West Africa: A Case Study of Two Chinese Projects. The Journal of Developing Areas 27 21-32.

70. Anshan L (2016) Technology Transfer in China-Africa Relation: Myth or Reality, Transnational Corporations Review 8: 183-195.

71. Jiang X (2007) My seventeen years in Africa. Shanghai: Lexicographical Publishing House.

72. Anshan L (2011) Chinese medical cooperation in Africa: With special emphasis on the medical teams and anti-malaria campaign. Uppsala: Nordic African Institute.

73. An Ran (2007) African Students' Educational Needs and The Recruitment Style. High Education Exploration 5: 110-13.

74. In Shikwati J (2012) China-Africa Partnership The Quest for a Win-Win Relationship (Nairobi: Inter Region Economic Network): 104-15.

75. Haugen $\mathrm{H} \varnothing$ (2011) Chinese exports to Africa: Competition, complementarity and cooperation between micro-level actors. Forum for Development Studies 38: 157-176.

76. Wenping $\mathrm{H}$ (2007) A summary analysis of China-Africa educational exchanges and cooperation: development phases and challenges. West Asia and Africa 3: $13-18$.

77. Jiangtao L, Xiang L (2006) China is my second hometown: African students life in Beijing. 